DOI 10.2478/linpo-2018-0008

\title{
Specialist languages in translation: the case of selected expressions of property law
}

\section{Linas Selmistraitis $^{1}$ \& Katarzyna Gęborys $^{2}$ \& Marek Krawiec ${ }^{3}$}

\author{
${ }^{1}$ Education Academy of Vytautas Magnus University, Vilnius \\ ${ }^{2}$ Faculty of Finance and Management, The WSB University, Wrocław \\ ${ }^{3}$ Faculty of Education, Wielkopolska University of Social and Economic Studies, Środa Wielkopolska \\ linas.selmistraitis@vdu.lt, katarzyna.geborys@wsb.wroclaw.pl, marass24@wp.pl
}

\begin{abstract}
Linas Selmistraitis \& Katarzyna Gęborys \& Marek Krawiec. Specialist languages in translation on the basis of selected expressions of property law. The Poznan Society for the Advancement of Arts and Sciences, PL ISSN 0079-4740, pp. 107-118

The concept of specialist languages has been widely discussed and analyzed not only with respect to the linguistic field (in the context of which certain changes are anticipated in language as a communicational tool), or translation studies (including cultural aspects of expressions and their equivalents) but also with respect to strategies and techniques used in the foreign language teaching process. The main objective of this paper is to examine the language of law on a sample of selected Polish legal expressions (property law expressions) and their English equivalents. The article points to the ways of translating expressions from this specialist language and emphasizes the need to include some cultural aspects in the translation process. The article starts with a presentation of various views on translation, and then provides information on specialist languages, their types and features, leading subsequently to the analysis of certain terms and concepts of law and the ways of translating them.
\end{abstract}

Keywords: specialist language, translation, cultural issues, legal texts

\section{Introduction}

The notion of specialist languages is related to the linguistic division of languages (as presented, for example, by Furdal 2000) which allows for distinguishing not only codes, registers or sociolects but also different types or genres of languages. There are many ways of interpreting the notion of specialist languages, as witnessed by the number of definitions, implications and practices that have been developed by scholars and practitioners throughout the years.

This paper aims at describing specialist languages by showing evidence from the field of translation and by relating it to the context of intercultural communication. Translation as a complex operation on texts ought to focus on the process of making decisions, on 
the ultimate product (a translated text) and on the knowledge which is indispensable to provide accurate legal translation. For the purpose of this paper, the authors concentrate on selected equivalent expressions of the specialist language of law, which may reflect various meanings and which may lead to misunderstandings, if inaccurately translated.

\section{On the notion of translation}

Translation which has a lot to do with the notion of transferring a message hidden under certain linguistic expressions into other expressions (usually among languages) constitutes a vast field of study. This process encompasses not only linguistic forms of the involved languages and the 'content' of the message, but also cultural aspects of the languages in which the process of message transmission takes place, not to mention some aspects of teaching and learning translation in a successful and proper way.

Although the earliest attempts to describe translation would have to be searched for in the third millennium B.C., contemporary explanations of this concept can be found in the account of Roman Jakobson (1959: 233), who perceives it as "interpretation of verbal signs by means of some other language" and Peter Newmark (1982/2001), who discusses translation from the semantic (referring to the meaning) and communicative (focused on the effect) perspectives. Other explanations presented by scholars suggest that translation is "the replacement of textual material in one language (SL) by equivalent textual material in another language (TL)" (Catford 1965: 20) or "rendering the meaning of a text into another language in the way that the author intended the text" (Newmark 1988/2001: 5). A cultural perspective on translation implies rewriting an original text as determined by ideology and poetics (Lefevere 1992/2004) and inclusion of cross-cultural elements into this process (Bassnett \& Lefevere 1990). Furthermore, translation might be perceived as 'part of after life' thanks to which foreign texts can survive (Benjamin 1923) or as "the relation of the letter to the spirit, of the body of literalness to the ideal interiority of sense" (Derrida 2001: 184).

Translation as formulating messages expressed in one language (Source Language SL) and transferred into another one (Target Language - TL) involves a number of goals to be achieved. Its superior goal is to be effective. This criterion may be fulfilled if translation communicates a message, preserving not only the content but also linguistic structures and cultural elements (needed especially in the translation of professional, official, or legal documents) (Richard 2014). On this basis one can state that translation can be discussed from different angles and that it can be seen as a process and a product, which is a notion to be described more thoroughly in the subsection below.

\subsection{Translation as a process and a product}

Translation is defined by scholars in a variety of ways, and hence may be discussed from various perspectives. The two leading perspectives, which encourage one to view translation as a process and a product, suggest that it is not only the activity of achiev- 
ing the most faithful equivalent of the translated material but also the ultimate outcome of this activity. For the purposes of this paper, translation will be viewed from these two perspectives and will be presented both as an activity and a product (a translated term).

In the considerations on the issue in question one can relate to Górski (2015: 163) who sees translation as an "operation performed on texts". This view suggests that translation is a process, usually a unidirectional one, the constant elements of which involve: two languages, text relevance (both the input and output) as well as linguistic and cultural aspects (Kielar 1977: 31). In the opinion of Venuti (1995: 305):

translation is a process that involves looking for similarities between language and culture particularly similar messages and formal techniques - but it does this because it is constantly confronting dissimilarities. It can never and should never aim to remove these dissimilarities entirely. A translated text should be the site at which a different culture emerges, where a reader gets a glimpse of a cultural other and resistency. A translation strategy based on an aesthetic of discontinuity can best preserve that difference, that otherness, by reminding the reader of the gains and losses in the translation process and the unbridgeable gaps between cultures.

The nature of translation is to produce and express the original message (in the Source Language) with the closest and full equivalent (in the Target Language) so that it is clear to the receiver. However, effective translation requires intercultural competence which may be understood as the knowledge of culture, of social aspects of life, systems of values or communicational strategies, including verbal and non-verbal behaviours (JopekBosiacka 2011: 14).

Viewed as a process, translation, as already noted here, is an operation in which a translator is responsible for making accurate decisions, the result of which is approaching the transferred message and its content and providing proper equivalents. The notion to be highlighted at this point is a question of fidelity and its maintaining in translation. Buden et al. (2009: 199), following von Humboldt's theory of translation (of 1816/1909), stress the concept of fidelity, which in their opinion is indispensable and which guarantees good translation. Yet Humboldt postulates not to reject patriotic aspects in the translation process, as well as not to reject nation-building orientation. Thus, the process of translation ought to be culture-oriented in terms of formulating messages in the target language.

Translation, however, needs to be seen not only as a process but also as a product. Looking from this perspective, the interest is put on the ultimate text which as a product is to expose certain features of accurateness, effectiveness, meaningfulness, and clarity. A product is a concrete translation material which is expected to remain the same in terms of its meaning. Translation as a product may illustrate the effects of the production process with all its strong and weak points (Buden et al. 2009: 202).

On the basis of the above considerations one can conclude that translation is, on one hand, a process which involves transferring the concept of a term from one language to another with due care of faithfulness and with awareness of responsibility, and on the other hand, an ultimate product of this process.

Bearing all this in mind it is crucial now to relate translation to the domain of specialist languages and to point to its role in conveying messages and meanings in the area of law. 


\subsection{Translation of specialist texts}

Translation as such is recognized as a complex process, yet, in the opinion of Jonston (2002: 27-28), "virtually by definition, a translation is a more intrinsically negotiable commodity than an original piece of writing, essentially because the translation is itself the end result of a complex process of negotiation out of the source language". To discuss specialist languages in the context of translation, it is crucial to take as a starting point "mutual dependence between professional knowledge and language of texts used in the context of specialist communication" (Jopek-Bosiacka 2006: 10). The diversity of knowledge and languages underpins special languages which influence the reception of texts by experts and non-professional addressees. The translation of specialist texts (legal ones in particular) aims at achieving communicational goals, yet with specific attention focused on conveying messages, cultural elements and imposed lines of interpretation. Grucza (2009: 25) emphasizes the impossibility of translating a specialist text into a text expressed in the primary (basic) language while maintaining the same informational value.

Translation of legal texts, apart from linguistic skills, requires from a translator not only familiarity with a legal jargon, but also skills of explaining certain legal concepts with reference to their cultural aspects. Cultural adaptation is in turn necessary to provide the best quality of the translated material since there is a constant need to migrate between cultures (Buden et al. 2009: 209). This cultural adaptation applies, however, not only to legal texts but also to other texts as well (e.g. literary texts).

Jopek-Bosiacka (2006) perceives the aspect of legal texts interpretation as a barrier for translation because a translator of legal texts needs to obtain specialist knowledge. The interpretation of law is a process which involves not only decoding (the concepts of legislator which are, in turn, imposed on a society), but also extra-textual aspects among which it is necessary to point to culture (other extra-textual aspects relate to the sender, recipient, intention, medium, time, place, text function) (Nord 1991: 37). The aspect of culture should not be separated from translation (Bassnett \& Lefevere 1990: 18), thus focusing only on the linguistic dimension would deprive translation of other elements, and rejecting culture would even constitute a peril for the process itself.

There are, however, problematic aspects of cultural adaptation, one of which is different origins. It is usually noticeable during translation of legal Polish texts to be used in the British culture since these two legal cultures have different origins.

\section{Specialist languages in the light of linguistic issues}

In order to discuss the notion of specialist languages, it is crucial to depart from the concept of language. Lyons (1981) provides several definitions of language, following the proposals of Sapir, Bloch and Trager, Hall and Chomsky, and finally concludes that languages are "systems of symbols designed for the purpose of communication" (Lyons 1981/2002: 8). With the development of languages, it is possible to distinguish specialist languages as sets of sub-codes (Cabre 2003), which are used in specific contexts or are used by a given community in a specific domain (Motos 2013: 9). 
In the view of Crystal (1997/2003: 3), language is a tool with distinguished syntactic, semantic and pronunciation rules common for "developing a special role recognized in every country". The ascribed role of a language is to be in force especially when there is a need to distinguish its varieties, purposes of its use or addressees.

As Crystal (1997/2003: 4) states, the role of a language may be its practical destination because as "the official language of the country it is used as a medium of communication in government, law courts, media and educational system". Thus we may speak of various genres of languages used for the purposes of specific receivers. Yet in order to comprehend roles or functions of languages, including languages for special purposes, one needs to observe relations between expressions (signs) and single objects or phenomena of the external world. The functions of expressions (texts) depend on many factors such as sense, purpose and intentions of the speaker (Żydek-Bednarczuk 2005: 197). The criterion to distinguish a specialist language (language for specific purposes) should not be dependent on the place of residence of the speaker or his origin or even nationality. On the contrary, the criterion ought to be related to the speaker's level of knowledge of the language and his profession (hence professional environment) which in turn would suggest a separate domain of language use, namely subject-specific knowledge (Goddard 2009).

\subsection{Language for special purposes - the language of law}

For many years, there have been ongoing disputes about the language for special purposes in terms of its definitional scope, as well as its purposes, equivalent expressions or even methods or strategies for teaching. Language for special purposes may be discussed not only from the perspective of linguistics or translation studies, but also applied linguistics, in which it is associated, unlike the language for general purposes, with context and the people involved (e.g. professionals in the field) (Widdowson 1983). Trace et al. (2015: 3) follow the concept of Strevens (1988) and state that language for special purposes involves both linguistics and content area knowledge that is specific to a particular context.

One of specialist languages is the language of law (legal acts, documents). Although this language is not governed by separate rules of semiotics and syntax, still it is recognized as a variety of language due to its specific terminology, or terminology used in specific contexts. In its legal perspective the language of law is defined as "a variety of the natural language in which the language of law is formed. While considering the language of normative acts, it is possible to speak of the language of legal provisions - which in the process of legal interpretation is subject to the transferring of legal norms into the language itself" (Kalina-Prasznic 2000: 314, translation ours). Thus, following Furdal (2000: 151) one may agree with the opinion about the lexical items that would influence the comprehension of the specialist language of law. In the consideration of the status of the language of law (among other types of language) it is worth referring to Malinowski (2006: 21) who states that this language is to be discussed through its reference to various language attributes, mostly to general or ethnic language. 
The language of law may be viewed as a lexical code, which in turn would be a synonym of a specific relation occurring between the party sending the code (usually a legislator) and its receiver. In this context, understanding this 'lexical code' requires from the addressee not only decoding legal messages but also interpreting complex legal texts in a proper way. Since the lexical code may be hidden in legal norms, it is worth following the opinion of Ziembiński (1997: 125) who notes that "[e]very domain of law consists (to some extent) of separate rules of coding the norms in the form of its provisions". Yet the manner of interpretation may differ depending on provisions contained in contracts, statues, bylaws or any acts of national or local law. On the other hand, Jopek-Bosiacka (2006: 11) believes that the language of law, especially in the context of international law, accomplishes the concepts of law, the content of which suggests its interdisciplinary character. An essential aspect of the language of law understood as a lexical code is the necessity to adapt its certain meanings into the target language (the language spoken by the population). Thus, with respect to its lexical part, the language of law may be analyzed similarly to a foreign language (in its metaphorical meaning). It seems reasonable to perceive the language of law as a variety of professional language whose aim is to describe meticulously the phenomena of a certain domain of knowledge, and also of culture (Snell-Hornby 2006: 54). Taking into consideration the purpose of using the language of law, it is necessary to note here that its superior objective is communication between communicative partners who are equally competent in the field of law (Jopek-Bosiacka 2006, 2011).

\subsection{Features of the language of law in the context of translational studies}

Among features influencing not only the quality of translations of legal expressions but also their understanding and interpreting one can distinguish both linguistic aspects (including inter alia metaphors, archaisms, synonyms) and the background knowledge of the receiver of such expressions. There is a need here to follow Wróblewski's (1948) division into the language of law (the language found in legal acts, provisions of law) and legal language (to be in use by lawyers, students of law, scholars in discussions on legal concepts, issues, or even provisions). A distinguishable feature of both types of languages is their formality.

Considering linguistic aspects of the language of law in the context of translation, it is crucial to mention archaisms, the use of which stems from the fact that the "legal language often strives toward great formality, it naturally gravitates towards archaic language" (Tiersma 1999: 95). In legal texts one may encounter expressions like: 'witnesseth' instead of 'witness' (thus with the morpheme 'eth'), 'forthwith' instead of 'right away' or 'hereinafter' instead of 'from this moment and later in this document' (Alcaraz \& Hughes 2002: 5).

The metaphorical context of translation ought to be understood as specific since metaphors may be found in texts of different origin and also in all types of widely comprehended legal texts (court rulings or court orders, literature on legal matters and legal rhetoric). The use of metaphors is the source of further research on motives and perception of different situations and contexts. The words 'defendant' or 'defense' refer, for 
example, to the concept of 'war', which is also the case of the Polish equivalent 'obrona'. Scholars maintain that metaphors are an indispensable part of the language of law. Berger (2002: 34), for instance, states that metaphors are "means of explaining complex or even abstract ideas", and hence "are strictly unavoidable in legal language because they are constitutive of legal reasoning" (Morra et al. 2006: 141). Metaphors enable one to make abstract concepts more concrete with the use of some strategies such as reification (to break the law - to be understood as 'naruszać przepisy prawa' instead of 'łamać prawo' or 'to break the contract - rozwiązać umowę instead of 'zrywać umowę') or personification ('in the eyes of law' - to be translated as 'w świetle prawa') (Richard 2014).

Another aspect to be discussed in the context of translation is the notion of synonyms which in the opinion of Chroma (2011: 39) reflect "the relationship established between or among units within one language and as such [...] can play an important role in intralanguage translation or interpretation mentioned above". At this point it is worth referring to Matulewska (2008: 59), who indicates that as a result of the development of law various sets of synonyms have been created since language (the language of law in particular) is subject to constant change and this change guarantees formulation of new concepts and new terminology.

All the features mentioned above must be taken into account in the translation process. By being aware of these features translators can do their work better and can avoid mistakes and problems which will be discussed in the forthcoming analytical section on the basis of selected expressions.

\section{Analysis of translation of selected expressions in the context of the language of law and in relation to inaccurate translation}

One of the challenges facing a translator of specialist texts is to provide the best quality of translation by using a specific language code which is "the representation of specialist knowledge" and "which ought to be treated as separate" (Grucza 2009: 25). Another challenge for a translator is the need to properly reflect cultural aspects as "differences between cultures may cause more severe complications for the translator than do differences in language structure" (Nida 1964: 130). Thus, in the translation of legal texts the most demanding competence is to be qualified in the field of law and only through this competence can one provide the most accurate translation of concepts of law. Translators, although not being educated in the field of law, are able to translate professionally once they have become accustomed to concepts of law and the specific register (or the language code). Yet the specific knowledge of a specific domain of life facilitates the process of making decisions and subsequently creating the ultimate product of the translation process. For the purposes of discussing the concept of specialist language translation, it is crucial to analyze the problem of inaccurately produced translations in the field of law.

In the translation of specialist languages, a translator may encounter various obstacles which relate, for instance, to the cultural adaptation. The terminological inaccurateness may stem not only from the difficulty to express the same idea or concept in the Target 
Language, but also to adapt certain terms to the needs of the receivers of the texts. This part analyses selected expressions from the area of property law translated from SL (Polish legal system) into TL (English legal system) and highlights errors which are made in translation of these expressions. This analysis will be based on the terminology presented by Myrczek-Kadłubicka (2014) in her account of Polish property law terms and their English equivalents.

Table 1: Property law expressions and their equivalents (part 1)

\begin{tabular}{|c|c|}
\hline Polish term & English equivalent \\
\hline Akt notarialny & Notarial deed/ notarial act \\
\hline Notariusz & Civil Law Notary/ Notary Public \\
\hline
\end{tabular}

Source: Myrczek-Kadłubicka 2014: 1, 36

The disputes on the choice of the most accurate equivalent term stems from the direction of translated expressions. Since 'notarial deed' seems to be an adequate expression of the Polish term, it is virtually impossible to reject 'notarial act', as this term seems typical of legislatures of mixed jurisdictions. Another term 'notariusz' seems to be more problematic in translation into English. Again, taking into consideration the source language and its reference to the Polish law, the term 'civil law notary' fulfills the criteria of the concept expressed in the Polish legal system (Law on the Notarial Profession Act - of 14th February 1991, as amedned). There is, however, a tendency to use the term 'notary public' which in turn is more target language oriented. In the context of the British legal system 'notary public' is the profession with a similar yet restricted competence (this competence is restricted to the certification of identity of parties signing an official document). Thus, in translating the term a translator ought to be aware of potential consequences of such a decision with reference to the context and potential addressee of the translated text.

Table 2: Property law expressions and their equivalents (part 2)

\begin{tabular}{ll}
\hline \multicolumn{1}{c}{ Polish term } & \multicolumn{1}{c}{ English equivalent } \\
\hline Hipoteka & Mortgage/ legal mortgage/ equitable mortgage \\
Księga wieczysta & Title register/ property register \\
\hline
\end{tabular}

Source: Myrczek-Kadłubicka 2014: 12, 21

In translating the term 'hipoteka' into English there is a need to rely on the receiver of the translation. To make the translation fit in with the Polish legal system, 'mortgage' is explicit enough to understand the legal concept, whereas in English law it is subdivided into 'legal mortgage' (as established in the common law system) and 'equitable 
mortgage' (created in the British system of equity, which results in a weaker position of a creditor). Another expression giving rise to terminological problems is the Polish term 'księga wieczysta' which is often translated into English as 'land register'. In such an expression the English term is misleading as for the British addressee 'land register' means a totally different concept, namely the court dealing with the procedure to register the land. A more accurate equivalent of 'ksiegga wieczysta' in the British law is 'title or property register' since the structure of the document resembles the structure of the Polish document.

Table 3: Property law expressions and their equivalents (part 3)

\begin{tabular}{lc}
\hline \multicolumn{1}{c}{ Polish term } & English equivalent \\
\hline Nieruchomości & Immovable property/ immovables/ land \\
\hline
\end{tabular}

Source: Myrczek-Kadłubicka 2014: 30

Depending on the definitional scope, the most meaningful equivalent of the Polish term 'nieruchomości' is 'immovable property', whereas for the British receiver of equivalent legal concept ('land') seems the most accurate term (it is worth mentioning that the scope of the British term is wider, still it is the context that ought to indicate the choice of the most appropriate term).

Table 4: Property law expressions and their equivalents (part 4)

\begin{tabular}{|c|c|}
\hline Polish term & English equivalent \\
\hline Służebność & Servitudes/ easements \\
\hline
\end{tabular}

Source: Myrczek-Kadłubicka 2014: 76

The concept of the Polish term 'służebność' relies on the Roman concept of 'rights in another person's property', the main aim of which is to tolerate certain acts of other people. The most proper British equivalent is 'easement' and the meaning refers to something which facilitates the usage of property.

Table 5: Property law expressions and their equivalents (part 5)

\begin{tabular}{ll}
\hline \multicolumn{1}{c}{ Polish term } & \multicolumn{1}{c}{ English equivalent } \\
\hline Własność & Ownership/ property \\
Współwłasność & $\begin{array}{l}\text { Co-ownership/ tenancy in common/ } \\
\text { joint tenancy }\end{array}$ \\
\hline
\end{tabular}

Source: Myrczek-Kadłubicka 2014: 110, 117, 119 
In the context of the Polish legal system, the term 'własność' translated as 'ownership' constitutes the widest right to protect this specific entitlement (Article 140 of the Polish Civil Code of 1962, as amended). However, while translating the term into English, translators may be misled as to the scope of this legal concept, and often they introduce the term 'full ownership'. The adjective 'full' may unconsciously lead to the confusion of types of ownership: full, half or part. It is advisable to avoid 'full' in order to be properly understood. The English equivalent 'property' reflects the scope of entitlements of the owner and is understood as the absolute one. Another Polish term 'współwłasność' translated as 'co-ownership' refers to the share of every co-owner, which enables them to decide freely on their parts. The British equivalent may also take the form of 'co-ownership', however further division depends either on the Roman law concept, and hence is expressed as 'tenancy in common' or may directly follow the institution of common law for the purpose of legal protection of shares, in the form of 'joint tenancy'.

The material presented here suggests that the translation of specialist expressions requires the knowledge of the field (the law in particular) and the proper decisions taken in the process of expressing the most faithful meaning in another language.

\section{Conclusions}

Translation as a broad concept encompasses not only strategies or techniques for maintaining the meaning, but also reflects the knowledge of the domain in which the translator operates. Both knowledge and education in any of specialist fields facilitates the process of translation and the process of decision making, and helps to achieve the meaningful product - the concrete translated material. However, translation of specialist languages requires from a translator familiarity with specific lexical terms, their meanings and contexts of their use. Another crucial aspect in the field of specialist language translation is the notion of culture which is to be recognized as an inseparable part of translation, the rejection of which would influence the quality of translation.

Translation of specialist language expressions is important also in the context of language learning and teaching. Yet in order to provide accurate training and teaching of students the teacher needs to be aware of and at least accustomed to the concepts (legal ones in particular) being taught. Only proper education may guarantee successful teacher-student communication and effective translation of messages by young people in real life.

On the basis of what has been presented above one may draw a conclusion that translation is a process which is conditioned by a number of factors (linguistic, cultural, social) and which properly done helps people to function across different languages, cultures, contexts and disciplines. The authors of this paper, by taking into account the information provided in the theoretical and analytical parts, put forward the opinion (similarly, for example, to Bassnett and Lefevere (1990) and Snell-Hornby (2006)) that the awareness of legal culture is crucial for the most faithful production of equivalent legal concepts. This awareness is built through education of translators and the development of their knowledge in the fields of law and the language of law. Therefore, the postulate to educate translators in a multidimensional way ought to be seen as true and valid. 


\section{References}

Alcaraz, Enrique Varo \& Hughes, Brian. 2002. Legal translation explained. Manchester: St. Jerome Publishing. Bassnett, Susan \& Lefevere, Andre. 1990. Translation, history and culture. London: Printer Publishers.

Benjamin, Walter. 1923. The task of the translator. In Venuti, Lawrence (ed.). 2000. The translation studies reader, 15-23. London, New York: Routledge.

Berger, Benjamin L. 2002. Trial by metaphor: Rhetoric, innovation, and the juridical text. Court Review. The Journal of the American Judges Association 39(3). 30-38. http://digitalcommons.unl.edu/ajacourtreview/133. Web.

Buden, Boris \& Nowotny, Stefan \& Simon, Sherry \& Bery, Ashok \& Cronin, Michael. 2009. Cultural translation: An introduction to the problem, and responses. Translation Studies 2(2). 196-219.

Cabré, Teresa M. 2003. Terminology: Theory, methods and applications. Terminology 9(2). 163-199.

Catford, John Cunnison. 1965. A linguistic theory of translation: An essay in applied linguistics. Oxford: Oxford University Press.

Chroma, Marta. 2011, Synonymy and polysemy in legal terminology and their applications to bilingual and bijural translation. Research in Language 9(1). 31-50.

Crystal, David. 1997/2003. English as a global language. Cambridge: Cambridge University Press.

Derrida, Jacques. 2001. What is a 'relevant' translation'? (translated by Lawrence Venuti). Critical Inquiry 27(2). 174-200.

Furdal, Antoni. 2000. Językoznawstwo otwarte. Wrocław: Zakład Narodowy im. Ossolińskich.

Goddard, Christopher. 2009. Where legal cultures meet: Translating confrontation into coexistence. Investigationes Linguisticae XVII. 168-205.

Górski, Tomasz. 2015. The Polish kodeks spółek handlowych [the commercial companies code] in English: Selected translational and terminological issues. In Błaszak, Marek (ed.), Money, banks and business in British and American literature, culture and language, 163-181. Warszawa: CeDeWu.

Grucza, Sambor. 2009. Kategoryzacja języków specjalistycznych w świetle antropocentrycznej teorii języków ludzkich. In Szadyko, Stanisław (ed.), Komunikacja specjalistyczna, Vol. II. Specyfika języków specjalistycznych, 15-30. Warszawa: KJS.

Humboldt, Wilhelm von. 1816/1909. Einleitung zu Agamemnon. In Leitzmann, Albert (ed.), Aeschylos'Agamemnon metrisch übersetzt. Gesammelte Schriften, Vol. 8, 119-146. Berlin: Behr's Verlag.

Jakobson, Roman. 1959. On linguistic aspects of translation. In Bower, Reuben A. (ed.), On translation, 232-239. Cambridge, MA: Harvard University Press.

Jonston, David. 2002. Translation for the stage: Product and process. Maynooth: Maynooth University.

Jopek-Bosiacka, Anna. 2006. Przektad prawny i sadowy. Warszawa: WN PWN.

Jopek-Bosiacka, Anna. 2011. Defining law terms: A cross-culture perspective. Journal Research in Language 9(1). 9-29.

Kalina-Prasznic, Urszula (ed.). 2000. Encyklopedia prawa. Warszawa: C.H. Beck.

Kielar, Barbara Zofia. 1977. Language of the law in the aspect of translation. Warszawa: Wydawnictwo Uniwersytetu Warszawskiego.

Lefevere, Andre. 1992/2004. Translation, rewriting and the manipulation of literary fame. Shanghai: Shanghai Foreign Language Education Press.

Lyons, John. 1981/2002. Language and linguistics. Cambridge: Cambridge University Press.

Malinowski, Andrzej. 2006. Polski język prawny: Wybrane zagadnienia. Warszawa: LexisNexis.

Matulewska, Aleksandra. 2008. Jakość przekładu prawniczego a cechy języka prawa. Język, Komunikacja, Informacja 3. 53-63.

Morra, Lucia \& Rossi, Piercarlo \& Bazzanella, Carla. 2006. Metaphor in language: Clarity or obscurity? In Wagner, Anne \& Cacciaguidi-Fahy, Sophie (eds.), Legal language and the search for clarity: Practice and tools, 141-174. Bern: Peter Lang.

Motos, Raquel Martinez. 2013. The role of interdisciplinarity in lexicography and lexicology. In Balteiro, Isabel (ed.), New approaches to specialized English lexicology and lexicography, 3-13. Newcastle upon Tyne: Cambridge Scholars Publishing.

Myrczek-Kadłubicka, Ewa. 2014. Egzamin na thumacza przysięłlego: Przewodnik po prawie cywilnym - prawo rzeczowe i spadkowe. Warszawa: C.H. Beck.

Newmark, Peter. 1982/2001. Approaches to translation. Shanghai: Shanghai Foreign Language Education Press. 
Newmark, Peter. 1988/2001. A textbook of translation. Shanghai: Shanghai Foreign Language Education Press.

Nida, Eugene A. 1964. Towards a science of translating: With special reference to principles and procedures involved in Bible translating. Leiden: Brill.

Nord, Christiane. 1991. Text analysis in translation: Theory, methodology, and didactic application of a model for translation-oriented text analysis. Amsterdam, New York, NY: Rodopi.

Richard, Isabelle. 2014. Metaphors in English for law: Let us keep them. Lexis - E-Journal in Lexicology 8, Metaphor Studies in the English Language. 1-19.

Snell-Hornby, Mary. 2006. The turns of translation studies: New paradigms or shifting viewpoints. Amsterdam, Philadelphia: John Benjamins Publishing Company.

Strevens, Peter. 1988. ESP after twenty years: A re-appraisal. In Tickoo, Makhan L. (ed.), ESP: State of the Art, 1-13. Singapore: SEAMEO Regional Centre.

Tiersma, Peter M. 1999. Legal language. Chicago: University of Chicago Press.

Trace, Jonathan \& Hudson, Thom \& Brown, James Dean. 2015. An overview of language for specific purposes. In Trace, Jonathan \& Hudson, Thom \& Brown, James Dean (eds.), Developing courses in languages for specific purposes. (NetWork) [PDF document] 1-23. Hawaii: National Foreign Language Resource Center.

Venuti, Lawrence. 1995. The translator's invisibility: A history of translation. London, New York: Routledge.

Widdowson, H. G. 1983. Learning purpose and language use. London: Oxford University Press.

Wróblewski, Bronisław. 1948. Język prawny i prawniczy. Parts: 2 \& 3. Kraków: Drukarnia Uniwersytetu Jagiellońskiego.

Ziembiński, Zygmunt. 1997. Logika praktyczna, XX ed. Warszawa: PWN.

Żydek-Bednarczuk, Urszula. 2005. Wprowadzenie do lingwistycznej analizy tekstu. Kraków: Universitas. 